\title{
Extraction of Outer Membrane Vesicles from Vaccinal Strain of Bordetella pertussis as the First Step of a Vaccine Candidate Study Against Pertussis Infection
}

\author{
Maryam Sadat Soltani ${ }^{1}$, Fereshteh Eftekhar ${ }^{1 *}$, Fereshteh Shahcheraghi ${ }^{2}$, \\ Mojtaba Noofeli ${ }^{3}$, Seyed Reza Banihashemi ${ }^{4}$
}

1. Department of Microbiology and Microbial Biotechnology, Faculty of Life Sciences and Biotechnology, Shahid Beheshti University, Tehran, Iran

2. Department of Bacteriology, Pasteur Institute of Iran, Tehran, Iran

3. Department of Human Bacterial Vaccines Production and Research, Razi Vaccine and Serum Research Institute, Agricultural Research, Education and Extension Organization (AREEO), Karaj, Iran

4. Department of Immunology, Razi Vaccine and Serum Research Institute, Agricultural research, Education and Extention Organization (AREEO), Karaj, Iran

\section{ABSTRACT}

Background: Pertussis is still one of the major public health problems. The increase of the disease emerged in recent decades due to the replacement of the reactogenic whole cell vaccine with the safer acellular vaccine and the genetic diversity of the bacterium. As outer membrane vesicles (OMVs) obtained from Bordetella pertussis contains surface immunogenic antigen in its structure, it has an acceptable characteristic that could be considered as a good candidate for pertussis vaccine.

Materials \& Methods: Vaccinal strain BP134 strain of B. pertussis was cultured under standard conditions and OMVs were isolated by modifying the method without the use of ultracentrifuge. The isolated vesicles were examined by transmission electron microscopy and protein content was measured by the Bradford method. The expression of virulence factors was confirmed by SDS-PAGE and protein expression was confirmed by Western immunoblot. Pyrogenicity test and abnormal toxicity test were performed on extracted vesicles.

Results: The morphology of the vesicles was confirmed in the range of 40 to $200 \mathrm{~nm}$. The protein concentration of the extracted vesicles was determined as $600 \mu \mathrm{g}$. Expression analysis by SDS-PAGE and western blot confirmed the presence of virulence factors, pertussis toxin, filamentous hemagglutinin, and pertactin using monoclonal antibodies in OMVs of the vaccinal strain. Pyrogenicity test and abnormal toxicity test were negative.

Conclusion: The proposed method is a simple and efficient method for isolation of the $B$. pertussis OMVs. The OMVs extracted from $B$. pertussis could be a candidate for a new generation of pertussis vaccine alone or in combination with adjuvants to design future acellular vaccines.

Keywords: Bordetella pertussis, pertussis vaccine, SDS-PAGE, Western immunoblot

Received: 2020/03/21; Accepted: 2020/06/10; Published Online: 2020/06/18

\begin{tabular}{|c|c|}
\hline Corresponding Information: & $\begin{array}{l}\text { Fereshteh Eftekhar, Department of Microbiology and Microbial Biotechnology, Faculty of Life Sciences and Biotechnology, Shahid } \\
\text { Beheshti University, Tehran, Iran. Email: f-eftekhar@sbu.ac.ir }\end{array}$ \\
\hline (c) (1) (9) & $\begin{array}{l}\text { This is an original open-access article distributed under the terms of the Creative Commons Attribution-noncommercial } 4.0 \text { International License which } \\
\text { distribution of the material just in noncommercial usages with proper citation. }\end{array}$ \\
\hline
\end{tabular}

Use your device to scan and read the article online

Soltani M S, Eftekhar F, Shahcheraghi F, Noofeli M, Banihashemi S R. Extraction of Outer membrane Vesicles from Vaccinal Strain of Bordetella Pertussis as the First Step of a Vaccine Candidate Study Against Pertussis Infection. Iran J Med Microbiol. 2020; 14 (3) :213-226

Download citation: $\underline{B i b T e X}$ | $\underline{\text { RIS | EndNote | Medlars | ProCite | Reference Manager | RefWorks }}$ Send citation to: $\Theta \underline{\text { Mendeley }} \mathrm{Z}$ Zotero $\dot{H}$ RefWorks 


\section{Introduction}

Pertussis is an acute respiratory illness that is highly contagious, especially in infants and children, and is caused by the gram-negative bacterium Bordetella pertussis (1). Pertussis is a reemergence disease and one of the ten most common causes of death from infectious diseases worldwide. Before vaccination was introduced, it was the main cause of infant death in the world. The main source of illness for the infant is family members, and transmission is often directly from one person to another (2).

The first generation of vaccines against the disease, the whole-cell pertussis vaccine (wP), was introduced in 1940. This vaccine uses the whole bacterium which has been killed by heat so that with widespread vaccination in the world, the number of cases decreased rapidly. Although, the vaccine was associated with side effects such as fever and local reaction at the injection site and encephalopathy, due to the high content of lipopolysaccharide, which is highly immunogenic (3). Due to the side effects of this vaccine, the second generation of the acellular pertussis vaccine (aP) was introduced and replaced in developed countries. aP vaccines contain inactivated pertussis toxin, along with recombinant or pure bacterial antigens of $B$. pertussis $(4,5)$.

WP provides immunity against a wide range of antigens, while aP creates immunity against a small number of antigens used in vaccine formulations. As a result, aP has low immune-stimulating activity and does not inhibit colonization in the respiratory tract so immunized individuals can be involved in the transmission of the disease in the population $(6,5)$.

In recent years, the re-emergence of pertussis has been observed in many countries with high vaccinated populations, and there has been a significant increase in the number of reported cases so that despite high rates of vaccination the disease is not yet controllable. Pertussis is an endemic disease, as well as the most common vaccine-preventable disease reported in industrialized countries $(\mathbf{8}, 7)$. In Iran, WP vaccines have been produced and used based on standard strain for many years, but despite high vaccination coverage, the number of patients with the disease has increased in recent years (9).

The resurgence of pertussis is associated with a variety of factors, including reduced immunity over time, gene mutations in bacterial antigens, and polymorphism in these genes, resulting in differences between the circulating strains and strains used in vaccine production was noted $(11,10)$. According to the mentioned points, due to the control of the disease, a new generation of vaccines is needed on which genetic polymorphism is not effective.

Outer membrane vesicles (OMVs) of B. pertussis contain outer membrane proteins (OMPs) and lipopolysaccharide (LPS) that have adjuvant properties and stimulate innate immune responses as well $(12,13)$. Unlike aP vaccines, these OMVs are easily absorbed by mammalian cells due to their nanoparticle properties and are harvested by antigen-presenting cells (APC) (14, 15). For this reason, to control pertussis disease, OMVs vaccine obtains from vaccinal strain are considered suitable candidates for the vaccine. Therefore, the extraction of these vesicles is of particular importance. To date, various methods have been proposed to stimulate the production and extraction of vesicles. The most important method is based on the use of serial ultracentrifugation (16). But lack of easy access of research and academic centers to ultracentrifuge in our country Iran is an important barrier for the extraction of OMVs. Therefore, the aim of this study was to provide a suitable and high-yield method for OMVs extraction of $B$. pertussis and to investigate the presence of virulence factors in it.

\section{Materials and Methods}

\section{Strain and Culture}

B. pertussis BP134 (vaccinal strain) provided by the Razi vaccine and serum research institute was used in this study. The bacterium was cultured on the BordetGengou agar medium.

\section{Isolation of OMVs}

Massive bacterial culture was performed to isolate OMVs on the modified Stainer Scholte (MSS) liquid culture medium (17). Colonies grown on BordetGengou medium were transferred to $50 \mathrm{cc}$ MSS liquid medium under sterile conditions and incubated at $35^{\circ} \mathrm{C}$ and $150 \mathrm{rpm}$ until bacterial growth reached the end of the logarithmic phase, turbidity equal to 0.7 to 1 at a wavelength of $600 \mathrm{~nm}$ (OD600 = 0.7-1), $10 \mathrm{cc}$ of which was inoculated to $500 \mathrm{cc}$ of the new MSS medium. It was shown as OD600 $=0.05$. This means that this turbidity was considered the initial turbidity for bacterial growth, then incubated at $35^{\circ} \mathrm{C}$ and $150 \mathrm{rpm}$. Taking into account the growth curve of the bacterium and considering that the best time to stop bacterial growth and start the OMV extraction process is at the end of the logarithmic phase and the beginning of the stationary phase, it seems that the best time to harvest a cell mass when the turbidity is 0.7 to 1 at a wavelength of $600 \mathrm{~nm}$.

By centrifuging the culture medium containing bacteria at $8000 \mathrm{~g}$ and at $4^{\circ} \mathrm{C}$ for 30 minutes, bacterial pellets were isolated and washed twice with phosphate buffer (PBS). In the next step, the pellets were completely dissolved in the Tris-EDTA buffer (TE; $8 \mathrm{ml}$ per gram of sediment) to create a uniform suspension. The suspension was then kept at room temperature for 
$30 \mathrm{~min}$ and sonicated for $10 \mathrm{~min}$ on ice. The suspension was centrifuged at $10000 \mathrm{~g}$ and $4^{\circ} \mathrm{C}$ for $20 \mathrm{~min}$. The pellets were washed with TE buffer and the supernatant was centrifuged at $60000 \mathrm{~g} \mathrm{C}$ for 2 hours at $4^{\circ} \mathrm{C}$. The pellets dissolved in the buffer contained Tris $(0.1 \mathrm{~mol})$, EDTA $(10 \mathrm{mM})$ and DOC $(5 \mathrm{~g} / \mathrm{L})$ to obtain a uniform suspension, then the suspension was centrifuged at $60000 \mathrm{~g}$ at $4^{\circ} \mathrm{C}$ for $2 \mathrm{~h}$. The supernatant was poured into a new microtube and the TE buffer was added to it and centrifuged again at $60,000 \mathrm{~g}$ and $4^{\circ} \mathrm{C}$ for one hour. Then, the obtained pellets were dissolved in $5 \mathrm{ml}$ of $3 \%$ sucrose and passed through the $0.22 \mu \mathrm{m}$ filter. The filtered sample (containing OMV) was inactivated by heating in $56^{\circ} \mathrm{C}$ water bath. To study sterility, the extracted vesicles were cultured in the blood Agar. OMV extraction was performed four times with this method, and each time, the size and spatial shape of the vesicles extracted with the TEM electron microscope were examined $(12,18)$. For this purpose, a carbon formvar grade was first prepared and negatively stained with potassium phosphotungstate. The grids were examined by Zeiss EM10C electron microscope (12).

\section{Measure the Amount of Vsicles Protein}

Bradford protein testing is a common method for measuring the concentration of proteins. OMV protein levels were measured according to this method (19).

\section{SDS-PAGE Electrophoresis and Western Blotting}

The protein profile of pertussis toxin, pertactin, and filamentous hemagglutinin proteins in OMVs extracted from vaccinal strain was evaluated using the SDS-PAGE method on $12 \%$ polyacrylamide gel (20). The coloring of the obtained protein bands was performed by Coomassie blue method and the final confirmation of PTX, PRN, FHA protein expression was prepared by the western blotting method using monoclonal antibodies (NIBSC No. 97/572, 97/558 and 97/564, respectively). NIBSC was performed using SMOBIO (PM2600) protein marker $(12,21)$.

\section{Pyogeny Test in Rabbits}

The pyrogeny testing of the extracted sample was performed according to the Pharmacopoeia method. To a group of five white rabbits produced by the Razi vaccine and serum research Institute, $3 \mathrm{mg} / \mathrm{mL}$ of OMVs were injected intravenously per kilogram of animal weight, and the same amount of PBS was injected into the control group. Then the rabbit's body temperature was measured every hour, until the third hour after the injection (22).

\section{Abnormal Toxicity Test}

The Abnormal Toxicity Test was performed to determine the harmlessness of the consumption of OMVs extracted in rabbits. A group of five white rabbits weighing 1.5 to $2 \mathrm{~kg}$ provided by Razi Vaccine and Serum Institute were injected intramuscularly with 3 $\mathrm{mg} / \mathrm{ml}$ of OMVs per kilogram of body weight. The rabbits were then kept in normal conditions for seven days. Temperatures were maintained in the range of 20 to $22^{\circ} \mathrm{C}$ and humidity around $60 \%$, and during this period, in terms of weight loss, side effects of the injection site and mortality were examined (22). In this study, the international standards of ethical rules for dealing with laboratory animals were observed.

\section{Results}

Since the bacterial culture in liquid medium and induction of stress in bacterial cells (the composition of the medium, cell harvest time and type of different stress conditions) in the liquid medium, affect the amount of vesiculation and OMV content. Harvest time is very important in the OMV extraction process. Considering that the best time to stop bacterial growth and start the OMV extraction process is the end of the logarithmic phase and the beginning of the stationary phase, which is about 30 hours after the initial culture according to the bacterial growth curve (Figure 1), harvesting was performed at this time.

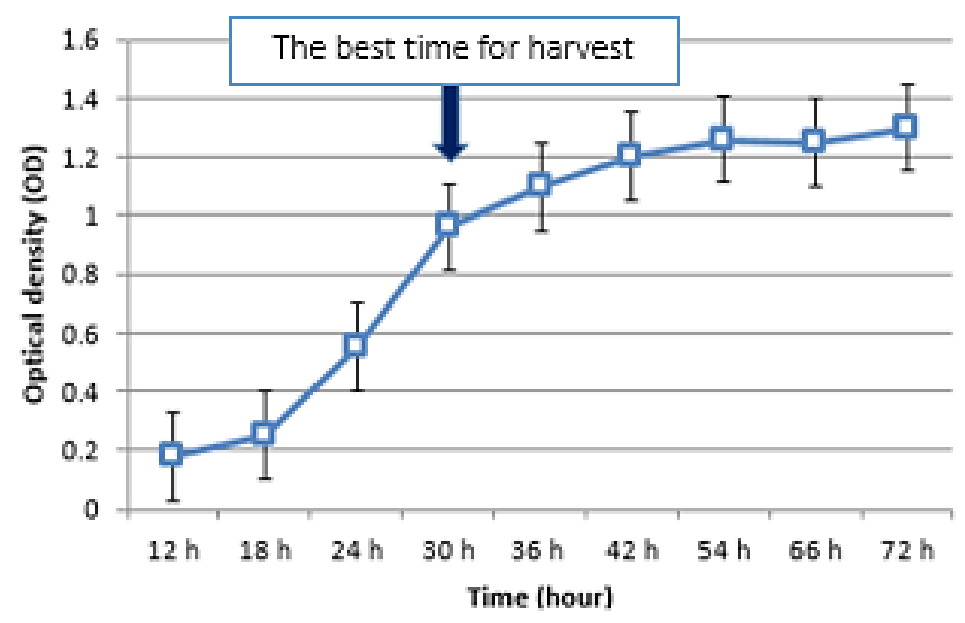

Figure 1. Growth curve of $B$. pertussis vaccinal strain 


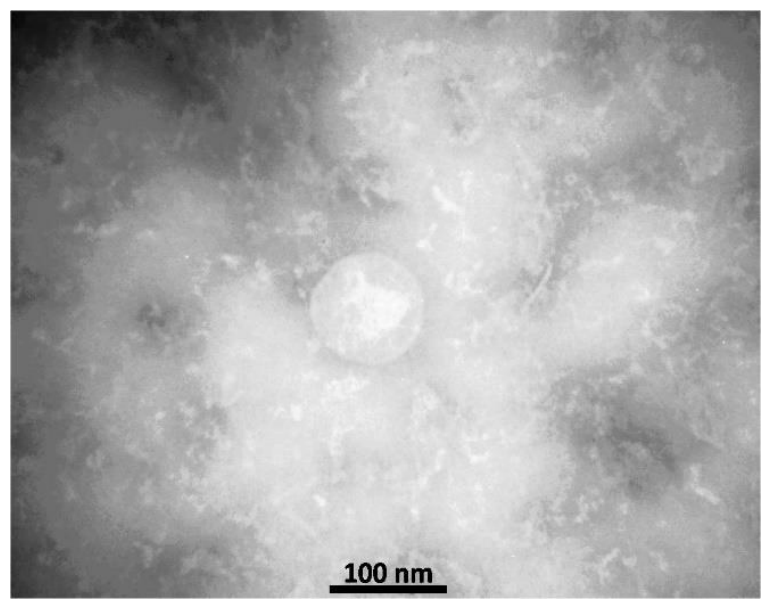

Figure 2. Electron micrograph of the extracted vesicles of $B$. pertussis

The morphology of the vesicles was confirmed by electron microscopy and its size was determined between 40 - 200 nanometers (Figure 2)

The protein content of the extracted OMVs was estimated at $700 \mu \mathrm{g} / \mathrm{ml}$. The profile of the proteins in extracted OMVs was observed by SDS-PAGE on polyacrylamide gel (Figure 3), presence of pertussis toxin, pertactin and filamentous hemagglutinin antigens in the extracted OMVs previously observed in the SDS-PAGE test confirmed by western blot test, using specific monoclonal antibodies, and completely specific bands were created for the antigens that were similar to the OMV isolated by the previous current method (Figure 4). OMV extraction was performed

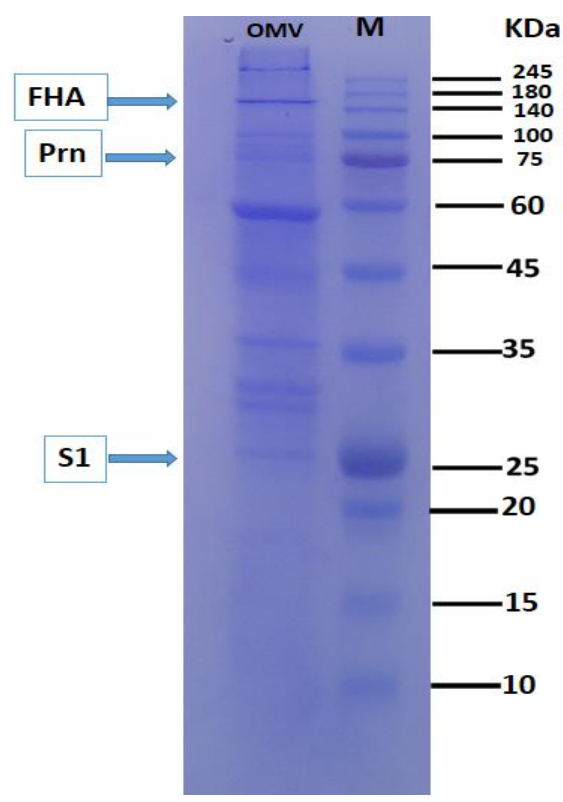

Figure 3. SDS-PAGE test of $B$. pertussis extracted with a protein marker four times independently, and each time the results were similar in morphology and size and similar to those previously performed.

With the injection of the extracted vesicles, the results of the pyrogeny test and the abnormal toxicity test were negative, so that no significant increase was observed in these tests, the increase in body temperature of any rabbit was not more than $0.7^{\circ} \mathrm{C}$, which indicates that extracted OMVs was not pyrogenic. Also, in the test for abnormal toxicity, none of the animal models lost weight, no side effects were observed at the injection site, and all rabbits survived until the end of the seventh day.

1

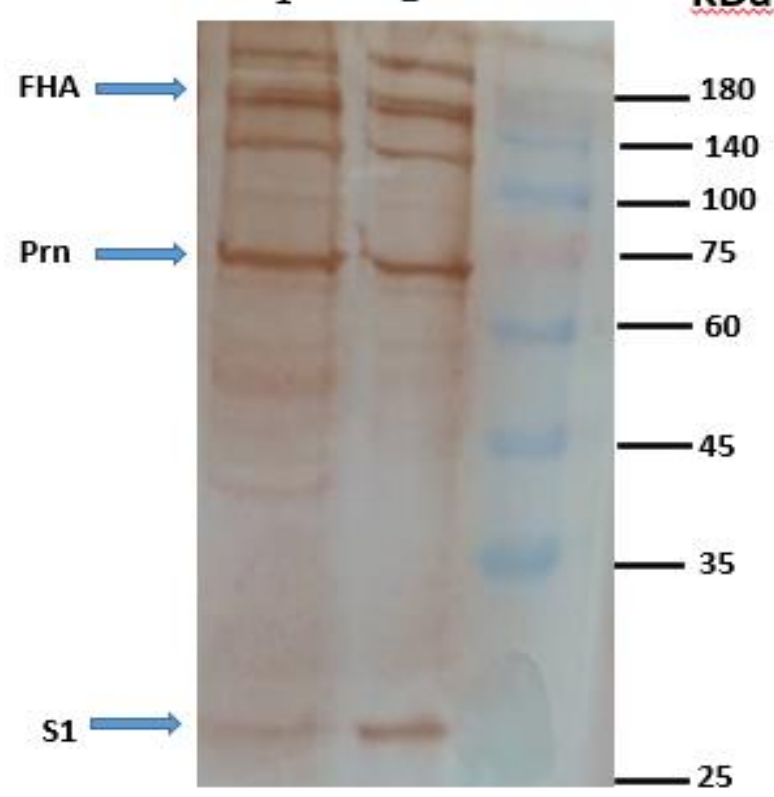

Figure 4. Western blot test using PTX, FHA and PRN monoclonal antibodies. (1) OMV obtained from the modified extraction method, (2) OMV obtained from the current extraction method 


\section{Discussion}

The resurgence of pertussis occurs despite widespread vaccination, and given the importance of more prevention of the disease, there is much debate today about pertussis vaccines. Acellular pertussis vaccines (aP) was developed and replaced in many developed countries due to the side effects associated with whole-cell pertussis vaccines (wP). These aP vaccines contain inactivated toxin along with recombinant or pure $B$. pertussis bacterial antigens such as pertussis toxin, filamentous hemagglutinin, pertactin, and fimbriae. These vaccines also have disadvantages, including the effectiveness of these vaccines depends on the number and concentration of antigens present in its formulation. While WP creates immunity against a wide range of antigens. The aP does not inhibit colonization in the respiratory tract, and immunized individuals can be involved in the transmission of the disease in the population $(23,24)$.

Other limitations of the aP pertussis vaccines include a rapid reduction of antibodies in the body after vaccination and induction of humoral immunity by the vaccine. Because $B$. pertussis is an intracellular bacterium, the humoral response is not the acquired immune response required for immunity against pertussis and cannot produce long-term immunity, so the cellular immune response plays an important role in clearing $B$. pertussis. Therefore, there is a great need for a third-generation pertussis vaccine to cover the weaknesses of previous vaccines. A vaccine should not only stimulate Th2 responses, but also stimulates Th1 and Th17 responses, like wP vaccine $(3,25)$.

Outer membrane vesicles of bacteria play an important role in physiology, pathogenesis, and interaction between host and pathogenic agents, and contain surface immunogens in their structure (26, 27). On the other hand, since overtime after vaccination, genetic modification of pathogenic and immunogenic factors of the bacterium $B$. pertussis has caused genetic modification of strains to protect the bacterium from the host immune system (28).

It seems that the main stimulate pressure for vaccine development is due to the generation of vaccine-escape mutants, such as those that do not produce pertactin. Such strain became dominant in many countries (29-31). The ability of OMV for protection with the help of several components, including Ptx, FHA and PRN, it introduces OMV as a vaccine candidate that selective pressure does not affect the circulating strains, and reduce the possibility of strains escaping the vaccine, so OMV has acceptable properties that can be used as a good candidate for the pertussis vaccine (18).

In 2013, Fernandez evaluated the possibility of using OMVs extracted from $B$. pertussis as a vaccine candidate, and with the use of western blotting, the presence of pertussis toxin, pertactin, and fimbriae, were confirmed. LAL (Limulus Amebocyte Lysate) has been shown to have lower endotoxin levels than a vaccine licensed in WP (14).

The contents of the vesicles of the outer membrane of the Tohama strain were examined using various techniques in a study by Robert and colleagues. The results showed the presence of known surface immunogens, such as pertactin, adenylate cyclase, pertussis toxin, and lipooligosaccharide. Considering the inherent safety induced in the airflow pathway and the protective immunity in the mouse model, it was shown that the OMV obtained from $B$. pertussis is considered as a candidate for protection against pertussis (12).

In a study by Raeven in 2016, the possibility of using OMVs as a candidate for the pertussis vaccine was investigated. Comparing OMV-containing vaccines with WP and aP vaccines, high levels of antibodies were observed, and the results showed that the extensive and regulated humoral response makes OMV vaccine a potential and promising candidate (32).

In a study by Gillard in 2014, outer membrane vesicles obtained from the recombinant strain of $B$. pertussis were formulated with the Tdap vaccine as a vaccine candidate evaluated, and the results were compared with conventional commercial vaccines. The findings showed that Tdapomv induced Th1 and Th2 immune responses and provided protection against clinical isolates, while the common commercial Tdap vaccine-induced Th2 but weakened Th1 response and provided little protection against the pathogen. According to Tdapomv, it can be considered as a new vaccine (33).

Also, the Bexsero ${ }^{\circledR}$ (previously $4 \mathrm{CMenB}$ ) vaccine, OMV isolated by the detergent in combination with the recombinant antigen, was introduced against Neisseria meningitidis serogroup B, developed by Bai et al. In 2011, and its immunogenicity was confirmed in clinical trials (34).

Extraction of the outer membrane vesicles of bacteria and their application in vaccine studies are developing nowadays. In previous studies, ultracentrifugation with a speed of $100000 \mathrm{~g}$ was used to isolate the outer membrane vesicles $(12,16,33)$. Due to the unavailability of Ultracentrifuge in most research and academic centers in Iran, in this study, a new method for isolating OMVs of $B$. pertussis was presented. This method involves a series of simple high-efficiency steps that can be performed using high-speed centrifugation. Figure 2 confirms the natural spatial shape of the vesicles and the similarity of the extracted vesicles compared with previous studies. So that the size of the vesicles is $40-200 \mathrm{~nm}$, 
which corresponds to the results obtained from the extraction of the vesicle using ultracentrifugation method $(12,16)$.

\section{Conclusion}

Also, the results of SDS-PAGE and Western using monoclonal antibodies show that the vesicles extracted in the new method are similar to the previous current method and contain important immunogens such as pertussis toxin, pertactin and filamentous hemagglutinin, which can induce the host immune system. The extraction was repeated four times, and the morphological similarity, size, and presence of antigens were observed in all cases. Also, the harmlessness of using the vesicles obtained by the pyrogeny test and the abnormal toxicity indicates that the sample is not contaminated with impurities during the extraction process. Therefore, it is possible to use it in clinical studies in animal models. This method has many positive advantages and is beneficial economically compared to the current method, hence it can pave the way for the extraction of vesicles on a large scale without the need for ultracentrifugation. OMVs obtained from the vaccinal strain of $B$. pertussis can be considered as a candidate for a new generation of pertussis vaccine alone or in combination with adjuvants for new acellular vaccines design in the future.

\section{Acknowledgment}

The authors thank all those who helped them writing this article.

\section{Conflict of Interest}

Authors declared no conflict of interests. 


$$
\begin{aligned}
& \text { مجله ميكروبشناسى يزشكى ايران } \\
& \text { سال If ـ شماره r _ خرداد و تير 99"1 } \\
& \text { Journal homepage: www.ijmm.ir }
\end{aligned}
$$

\section{استخراج وزيكولهاى غشاى خارجى سويه واكسينال بردتلا برتوسيس بهعنوان اولين قدم}

\section{مطالعاتى كانديداى واكسن عليه عفونت سياه سرفه}

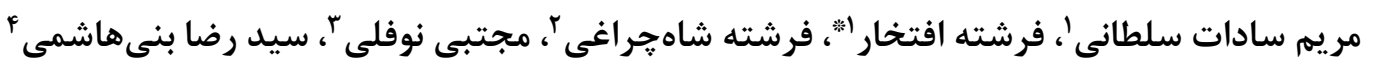

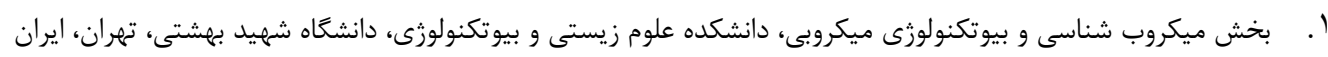

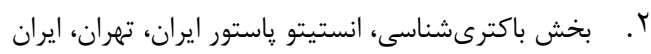

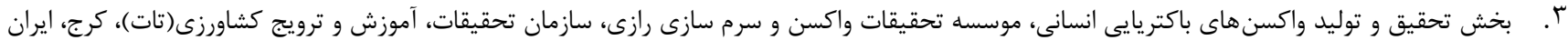

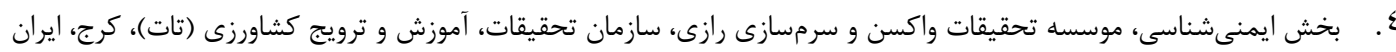

\section{جִكيده}

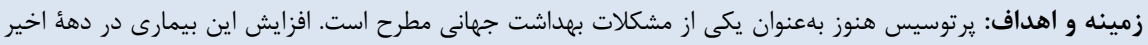

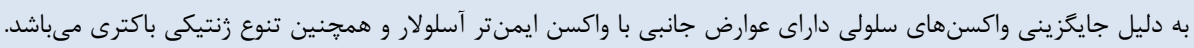

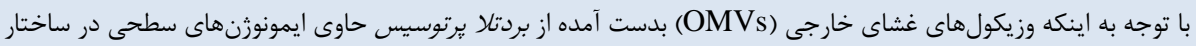

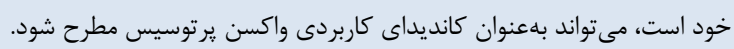

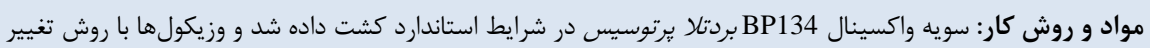

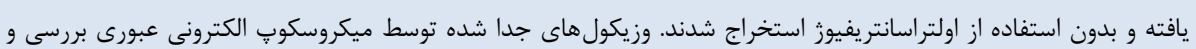

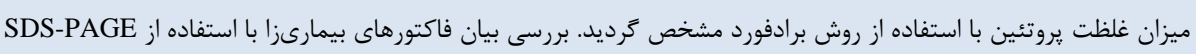

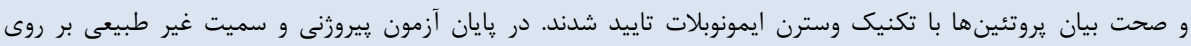

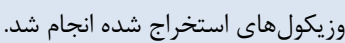

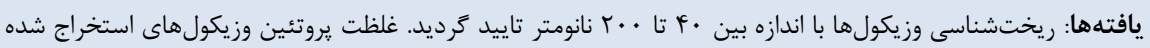

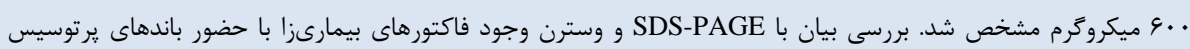

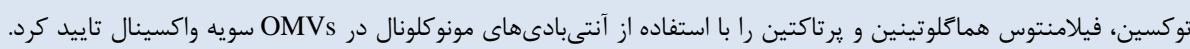

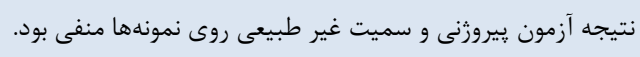

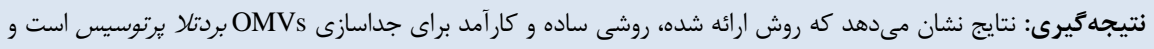

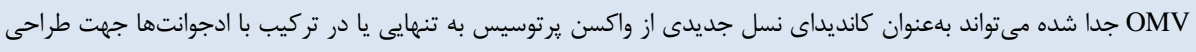
واكسنهاى آسلولار در آينده مطرح باشد. كليد وازهها: بردتلا برتوسيس، واكسن يرتوسيس، SDS-PAGE، وسترن ايمونوبلات.
اطلاعات مقاله

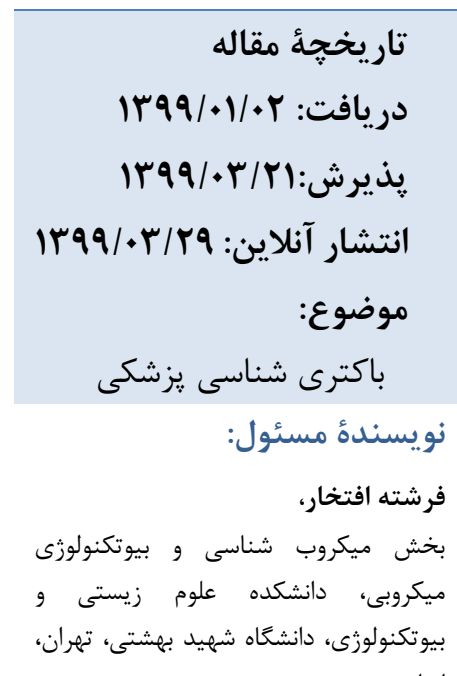

ايميل: f-eftekhar@sbu.ac.ir
واكسيناسيون، اصلىترين علت مرگ نوزادان در جهان بود. منبع

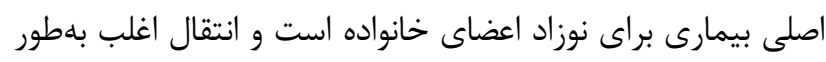

$$
\text { مستقيم از فردى به فرد ديكر صورت مى يذيرد (r). }
$$

اولين نسل واكسنها عليه اين بيمارى، واكسنهاى سلولى به نام (wP) whole cell pertussis vaccine در سال •94 اعرضه
بيمارى سياه سرفه (يرتوسيس)، بيمارى حاد تنفسى و به

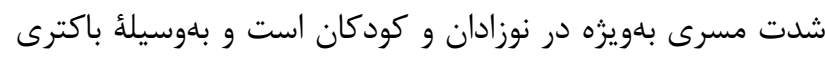

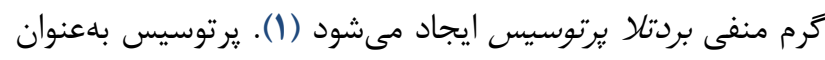

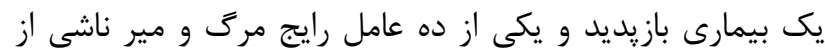

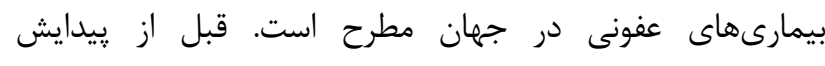


وزيكولهاى غشاى خارجى (OMVs) بردتلا برتوسيس داراى يروتئينهاى غشاى خارجى (OMPs) و لييويلى ساكاريد (LPS)

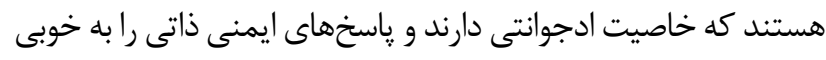

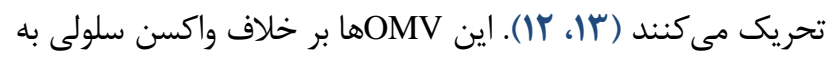
دليل خاصيت نانوذرات و دارا بودن ساختار يروتئولييوزومى به راحتى جذب سلولهاى پستانداران شده و توسط سلولهاى عرضه كننده

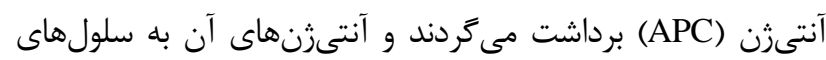

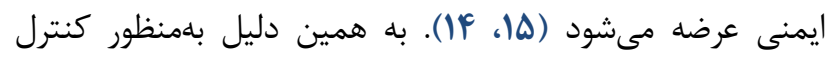
بيمارى يرتوسيس، OMVs سويه واكسينال بومى بهعنوان كانديداى مناسب واكسن مطرح شدند. از اين رو جداسازى اين وزيكولها اهميت

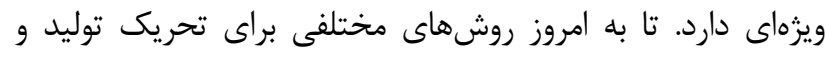

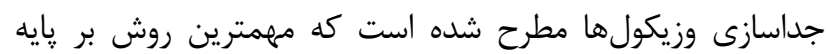
استفاده از اولتراسانتريفيوزهاى يى دريى است (19) كه عدم دسترسى آسان در مراكز تحقيقاتى و دانشكاهى به دستخاه اولتراسانتريفيوز در

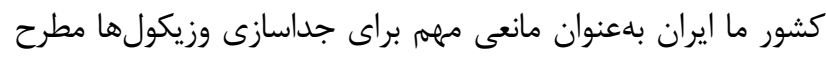

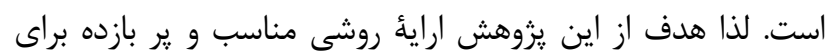
جداسازى OMVs سويه واكسينال باكترى بردتلا برتوسيس در ايران و بررسى وجود فاكتورهاى بيمارىزا در آن بود.

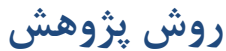

\section{انتخاب سويه و كشت}

در اين مطالعه از سويه واكسينال BP134 بردتلا برتوسيس فراهم شده از موسسه واكسن و سرمسازى رازى استفاده شد.

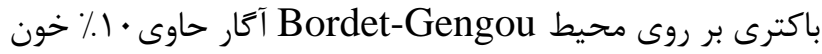
دفيبرينه كوسفندى كشت داده شد.

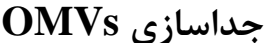

كشت انبوه باكترى جهت جداسازى OMVs بر روى محيط كشت مايع (MSS) modified Stainer Scholte) انجام شد ردائ (IV) (IV) كلنىهاى رشد يافته بر روى محيط Bordet-Gengou

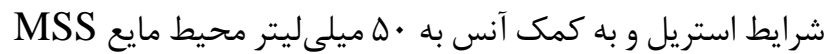

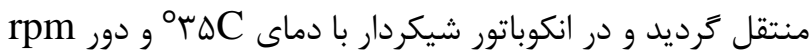

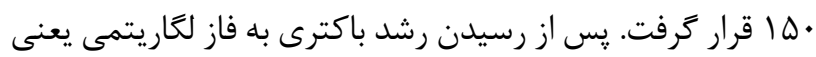

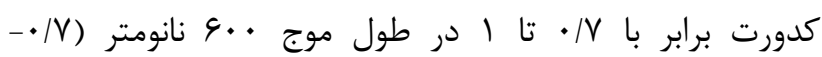

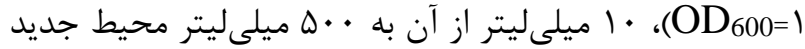

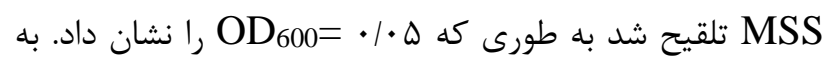

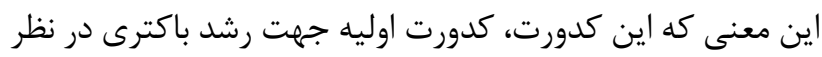

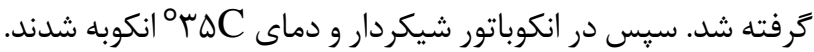

شدند. در اين واكسنها از بِيكر كامل باكترى كشته شده بهوسيلة

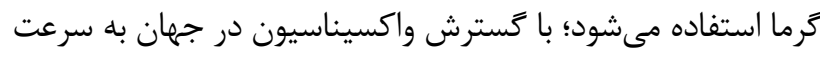

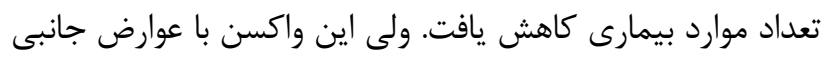

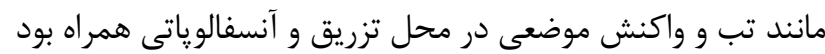
كه علت آن به دليل محتواى زياد ليبيويلى ساكاريد است كه به شدرت تحريك كنندة ايمنى مى باشد (ץ). به دليل اثرات جانبى اين واكسن،

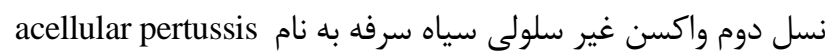
كشف و در كشورهاى ييشرفته جايگزين كرديد. واكسنهاى aP حاوى يرتوسيس توكسين غير فعال شده همراه با

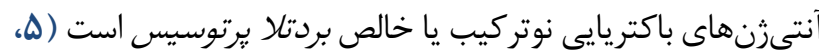

باعث ايجاد ايمنى عليه رنج وسيعى از آنتىزنها مىشود، در حالى كه aP ايمنى عليه تعداد كمى از آنتىزنها ايجاد مي كند إندا

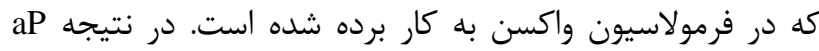

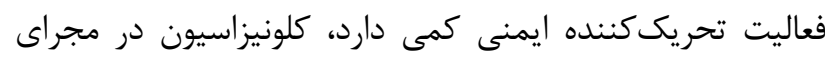

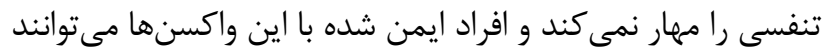
در انتقال بيمارى در جمعيت نقش داشته باشند (ه، ه).

در سالهاى اخير، ظهور مجدد يرتوسيس در تعدادى از

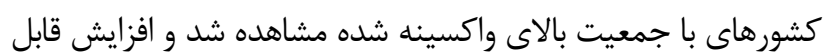
ملاحظهاى در تعداد موارد گزارش شده وجود داشت بلهطورى

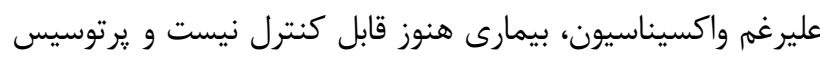

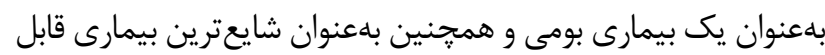

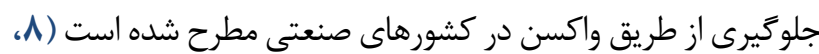
V). در ايران نيز سالهاست كه واكسن سلولى بر קايه سويه استاندارد

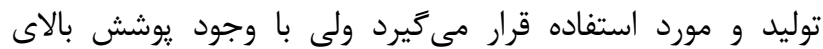

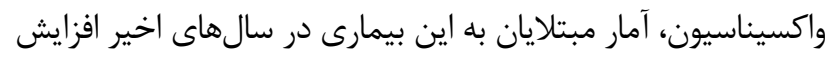

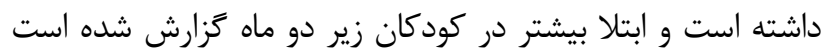

باز يديدى بيمارى سياه سرفه با فاكتورهاى مختلفى مرتبط است كه از اين ميان مىتوان به كاهش ايمنى ايجاد شده توسط واكسن

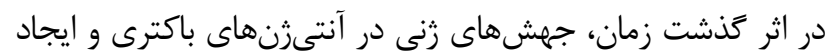
يلىمورفيسم در اين زنها و در نتيجه تفاوت سويههاى موجود در

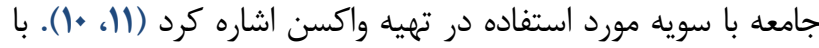
توجه به موارد ذكر شده، بهمنظور كنترل بيمارى، نياز به نسل جديدى نهائ

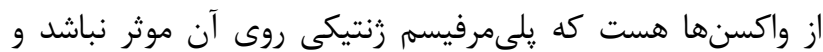
محدوديتهاى واكسنهاى قبلى را نداشته باشد. 


\section{الكتروفورز SDS-PAGE و وسترن بلاتينگ}

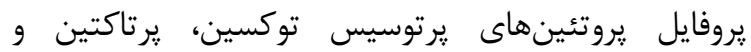

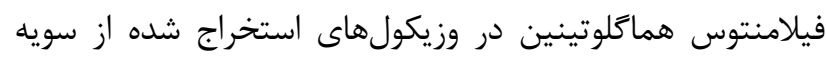

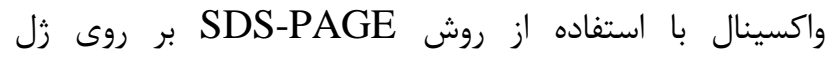

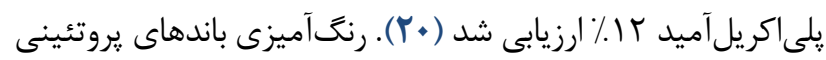

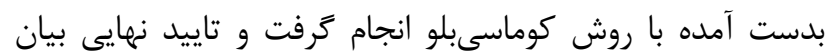

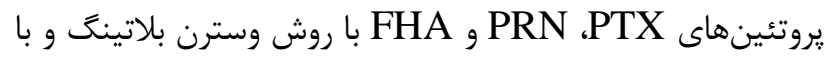
استفاده از آنتىبادىهاى مونوكلونال P78

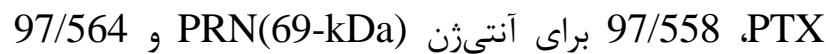

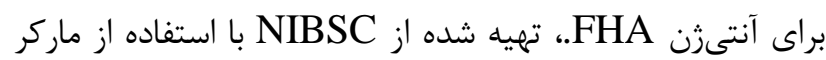

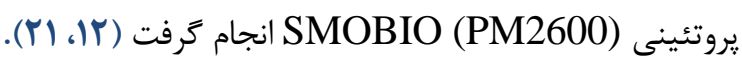

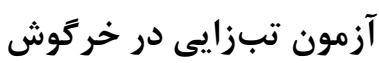

جهت بررسى تبزايى يا عدم تبزايى، آزمون يبيروزنى

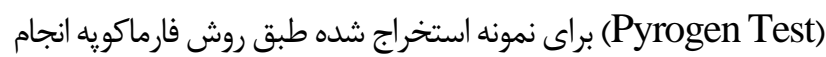

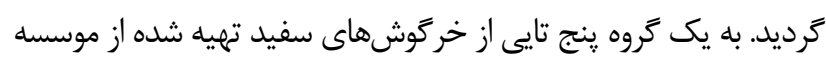

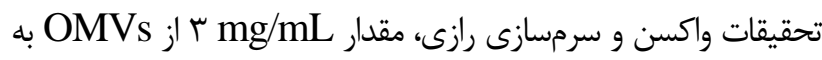

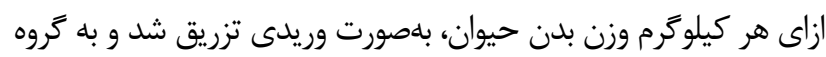

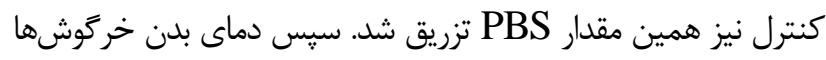

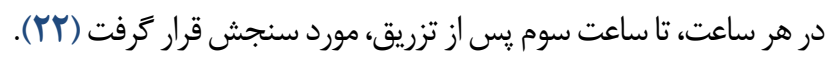

\section{آزمون ايجاد سميت غير طبيعى}

آزمون ايجاد سميت غير طبيعى ( Abnormal Toxicity Test براى تعيين بحزيانى مصرف OMVs استخراج شده در خر خركوش

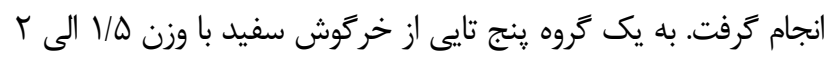
كيلوكرم فراهم شده از موسسه تحقيقات واكسن و سرمسازى رازئ بازي، مقدار

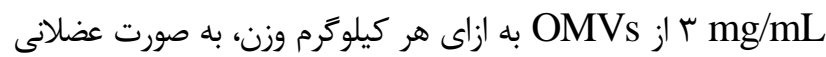

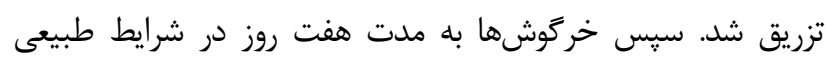

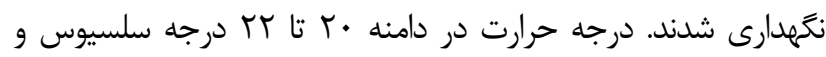

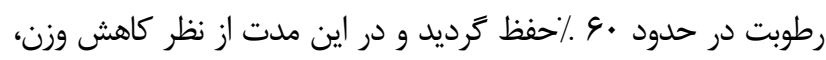

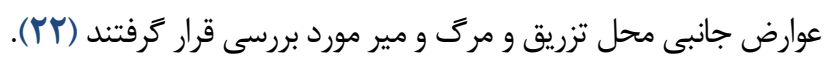

\section{يافته ها}

با توجه به اينكه كشت باكترى در محيطهاى مايع و القاء استرس

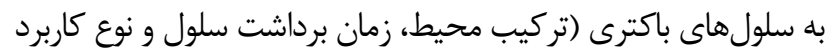

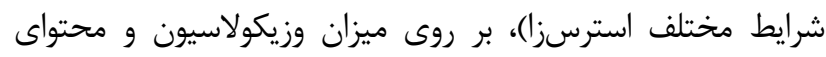

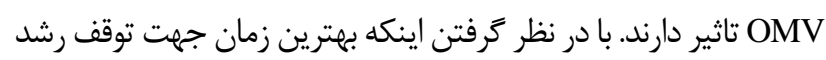

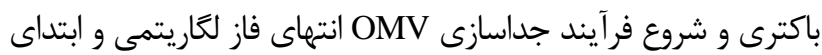

با توجه به اين كه بهترين زمان جهت توقف رشد باكترى و شروع

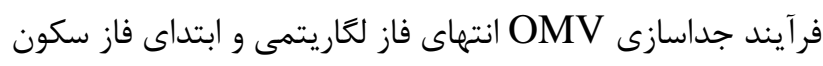

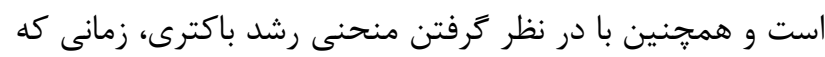

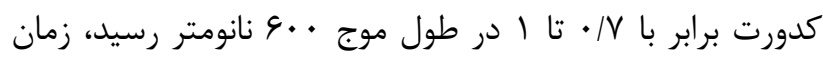
مناسب براى برداشت توده سلولى است.

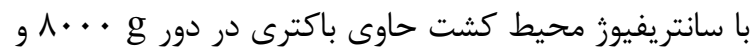

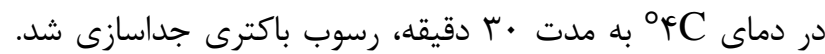

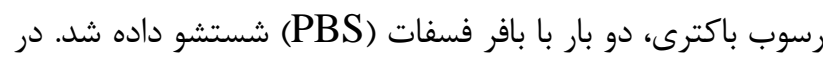

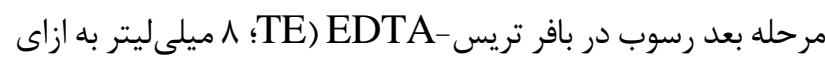

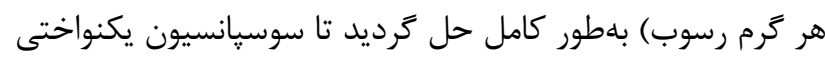

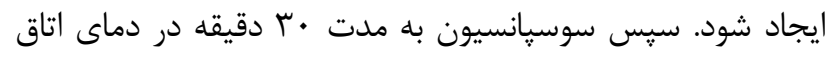

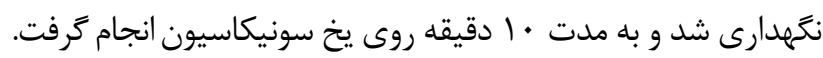

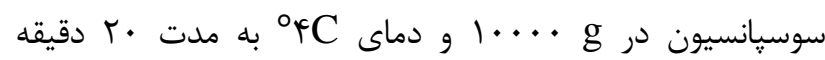

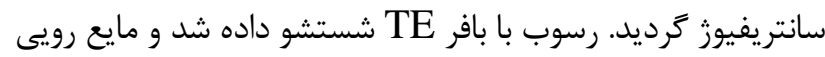

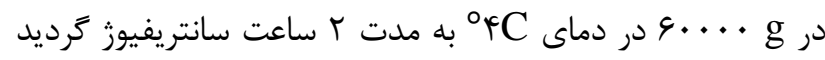

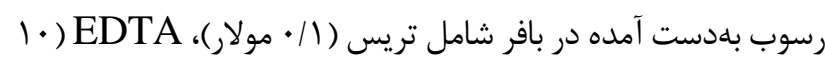

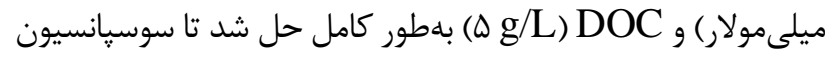

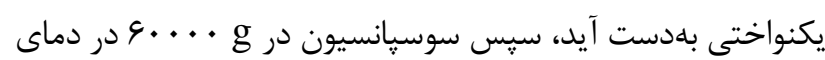

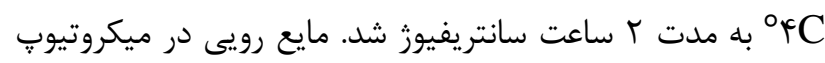

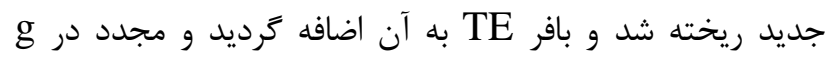

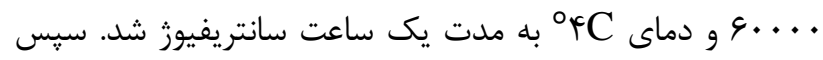

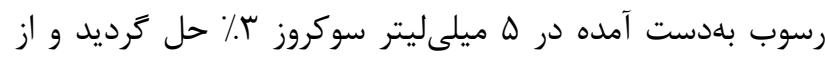

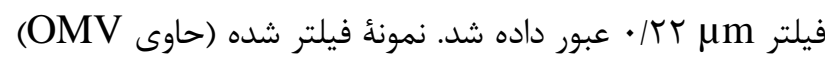

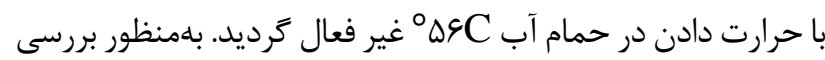

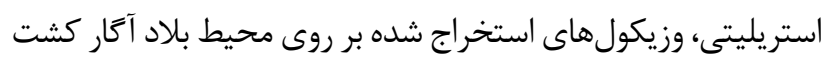

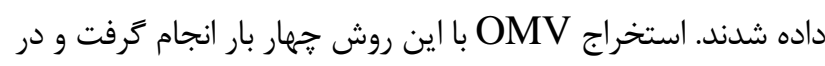

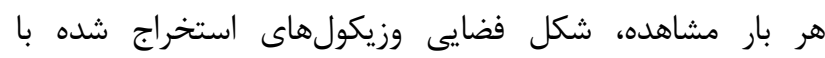

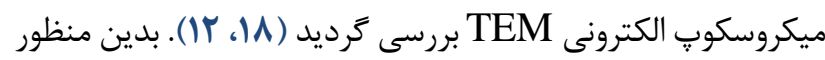

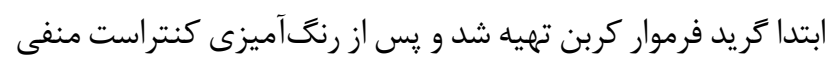

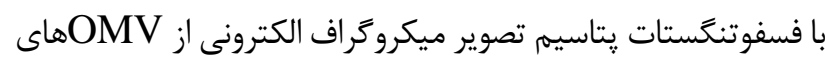
استخراج شده توسط ميكروسكوب الكترونى Zeiss EM10C تهيه تهايه

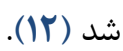

\section{سنجش ميزان يروتئين وزيكولها}

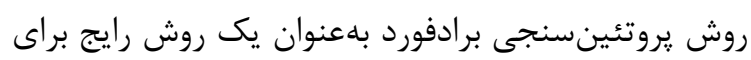

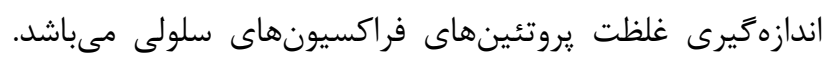
ميزان يروتئين OMV طبق اين روش اندازهيرى شد (19). 
ريختشناسى وزيكولها توسط ميكروسكوٍ الكترونى تاييد

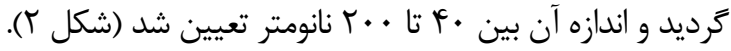

فاز سكون است كه بر اساس منحنى رشد باكترى (شكل ()، ^ب ساعت بعد از كشت مىباشد، برداشت در اين زمان صورت كرفت.

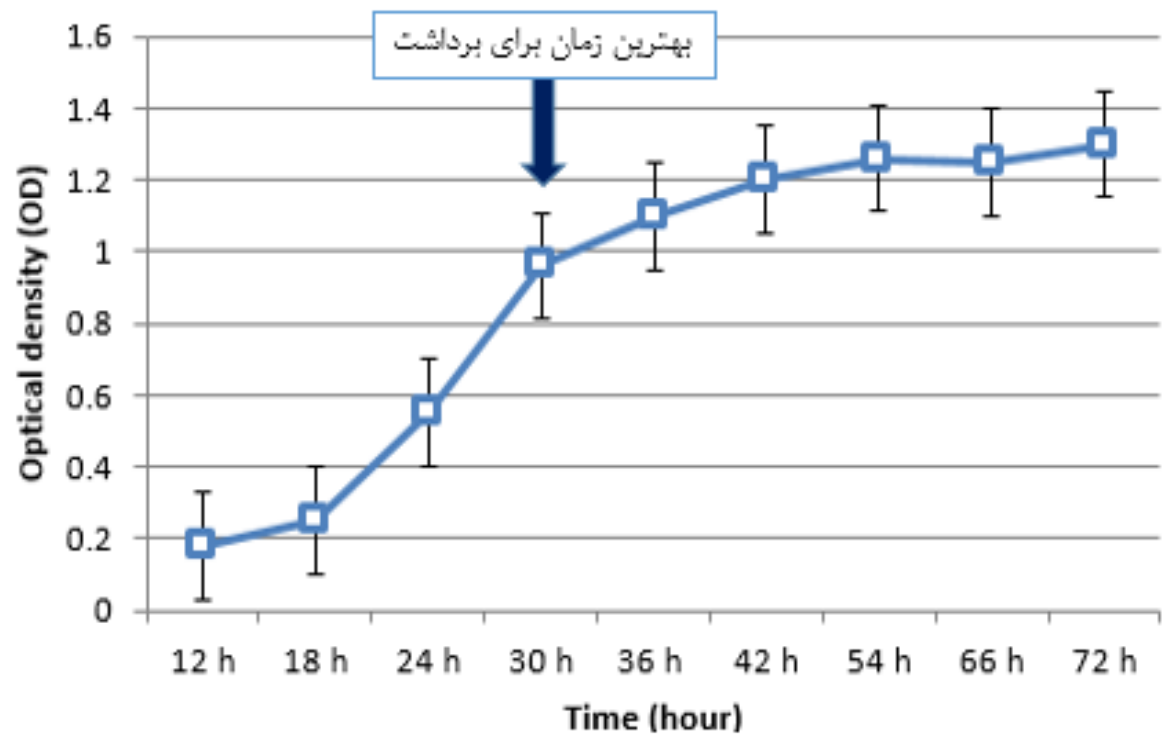

شكل ا. منحنى رشد سويه واكسينال بردتلا برتوسيس

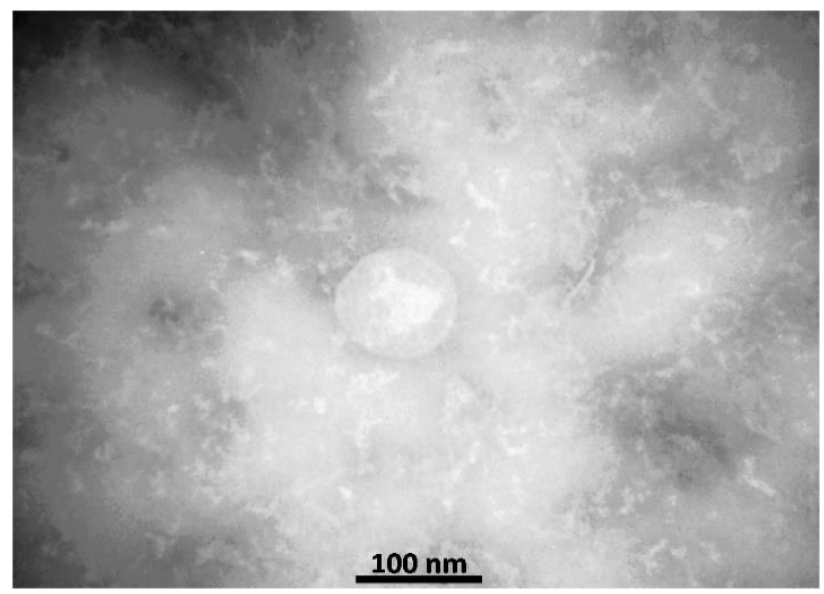

شكل r. ميكروكراف الكترونى از وزيكول هاى استخراج شده برنتلا برتوسيس

ريختشناسى و اندازه مشابه هم و مشابه مطالعاتى بود كه از قبل انجام

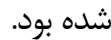

با تزريق وزيكولهاى استخراج شده، نتايج آزمون تبزايى و

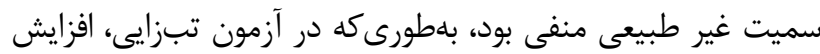

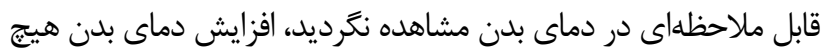

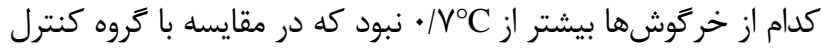
افزايش دما ديده نشد، كه نشاندهندة تبزا نبودن مان استخراج

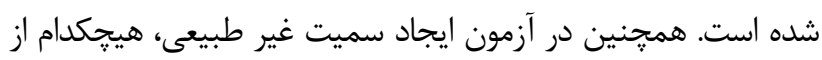

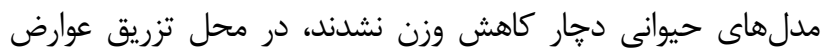

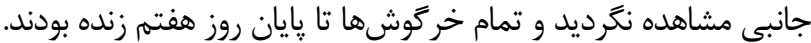

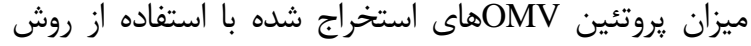

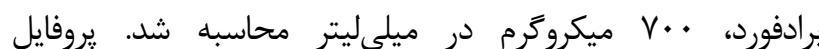

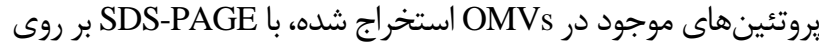

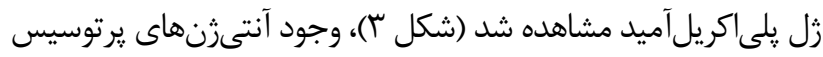

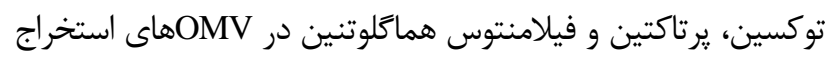
شده كه بيش از اين در آزمون SDS-PAGE مشاهده شده بودند، در آزمون وسترن بلات با آنتى بادىهاى منوكلونال اختصاصى تاييد شدند آندات آندان

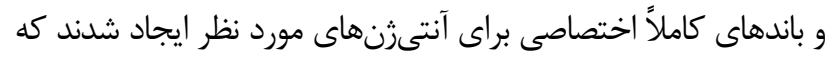

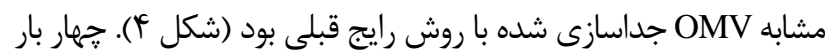
استخراج OMV بلطور مستقل انجام شد و در هر بار نتايج از لحاظ 


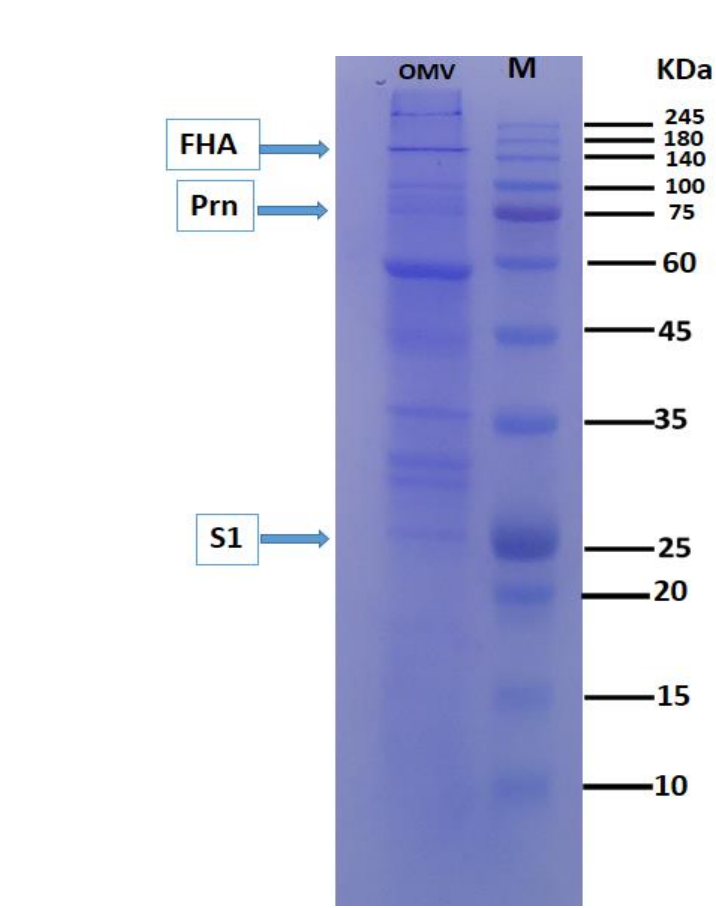

شكل س. آزمون SDS-PAGE وزيكول هاى استخراج شده بردتلا يرتوسيس در كنار ماركر يروتئينى

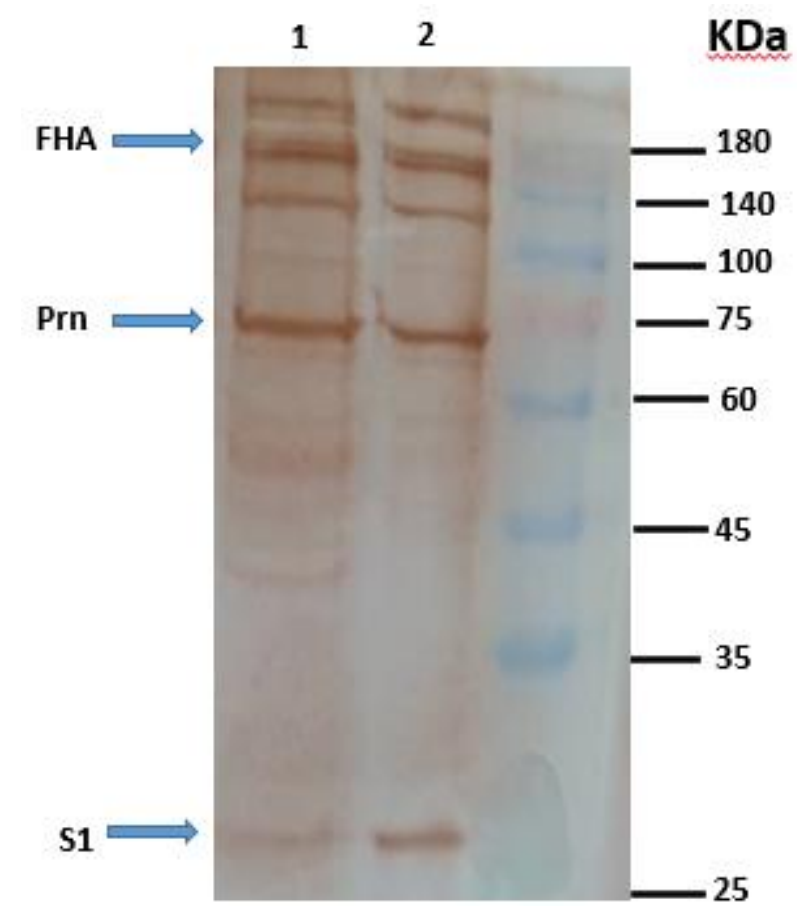

شكل F. آزمون وسترن بلات با استفاده از آنتى بادىهاى

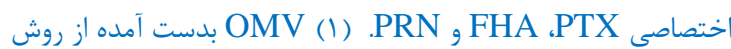

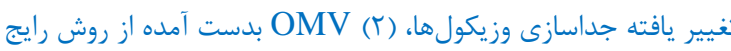
جداسازى وزيكول

بحث

קيدايش مجدد سياه سرفه علىرغم واكسيناسيون گسترده، اتفاق مىافتد و با توجه به اهميت كنترل بيشتر اين بيمارى، امروزه سياه سئه

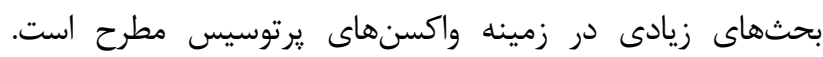
بهطورى كه با توجه به عوارض جانبى واكسن سلولى سياه سرفه (wP)، واكسن آسلولار (aP) توسعه يافت و در بسيارى از كشورهاى يِيشرفته

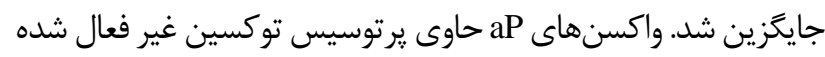

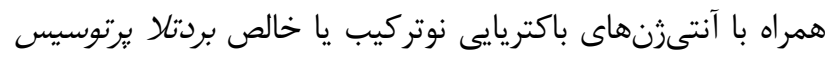

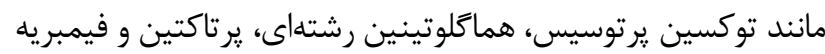

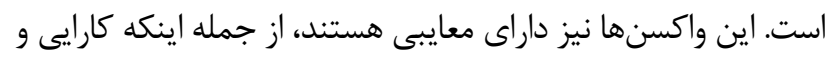

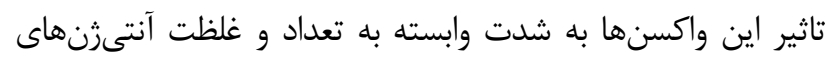

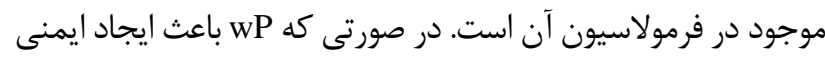

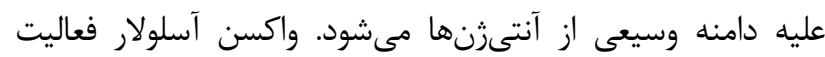

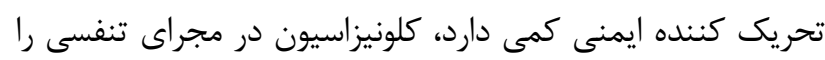

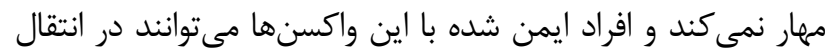

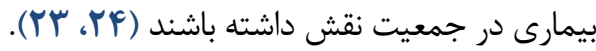
از ديخر موارد محدوديت واكسنهاى aP يرتوسيس، مىتوان

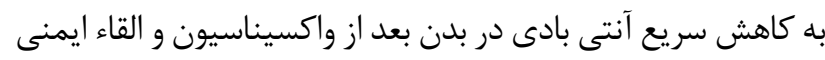
همورال توسط واكسن اشاره كرد. با توجه به اين كه باكترى بردتلا بلادي .
به نظر مىرسد فشار اصلى محرك براى تكامل سويهها فشار

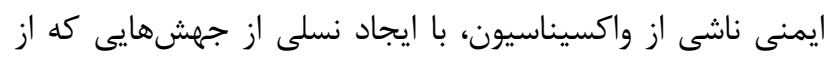

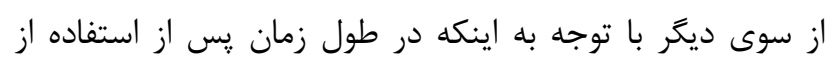

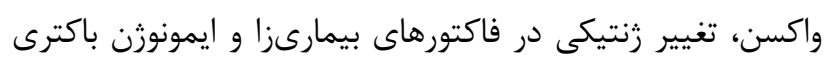
بردتلا برتوسيس باعث تغيير زنتيكى سويهها شده تا از اين طريق

باكترى از سيستم ايمنى ميزبان در امان بماند (YA).

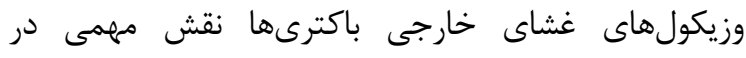

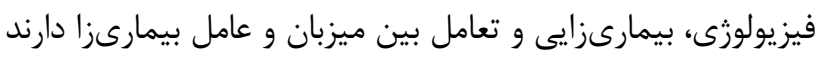

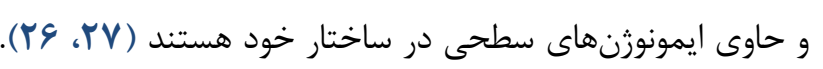


مى گردد و محافظت عليه عفونت جدايه بالينى ايجاد مى كند، در

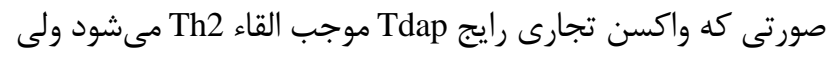

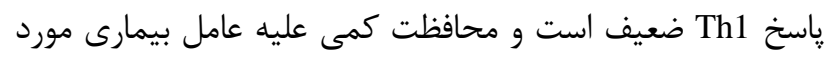
نظر ايجاد مى كند. بنابر اين Tdapomv مىتواند بهعنوان واكسن خند

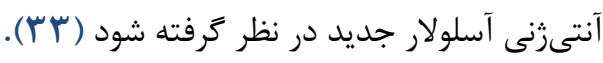

OMV ، همجنين واكسن جداسازى شده به وسيله دترجنت در تركيب با آنتىزن نوتركيب

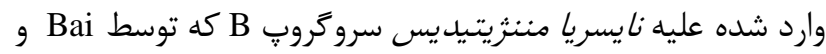

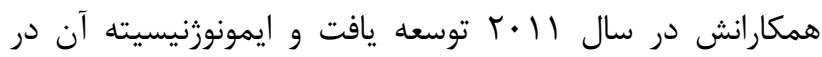

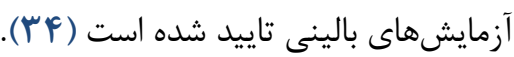

با توجه به اين كه جداسازى وزيكولهاى غشاى خارجى

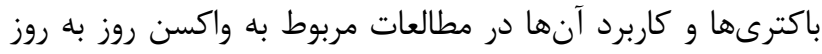

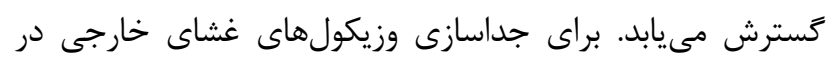

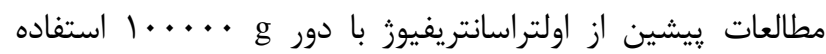

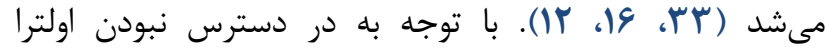

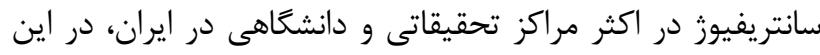

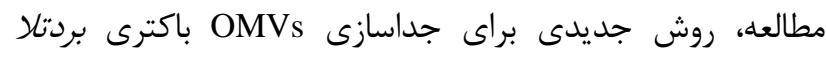
برتوسيس ارائه شد. اين روش شامل يك سرى مراي مراحل ساده با باليا

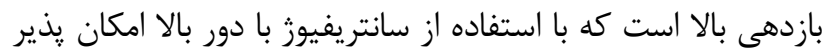

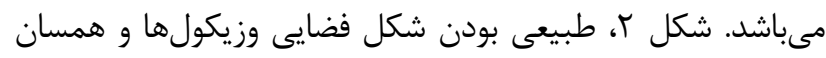

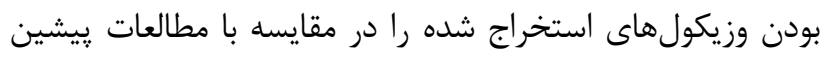

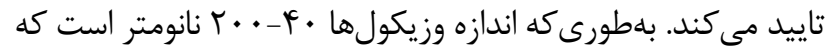
با نتايج بهدست آمده از جداسازى وزيكول با روش اولتراسانتريفيوز

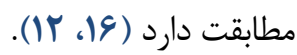

\section{نتيجه}

همجنين نتايج SDS-PAGE و وسترن با استفاده از

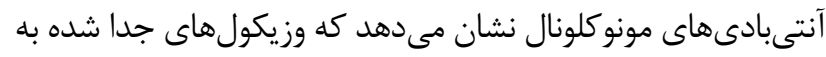

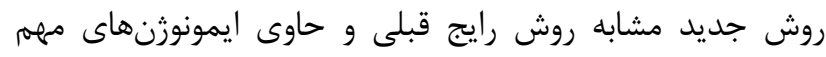

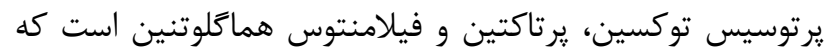

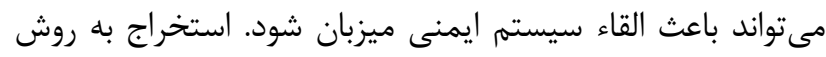

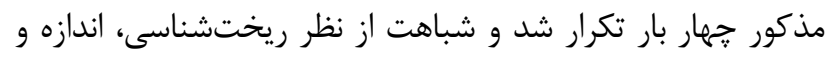

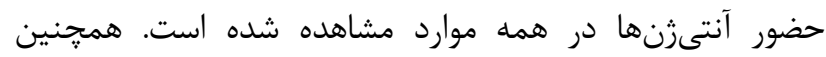

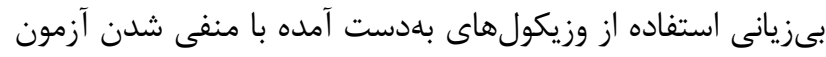
تبزايى و سميت غير طبيعى بيانكر عدم آلودكى نمونه با ناخالصى أمدها

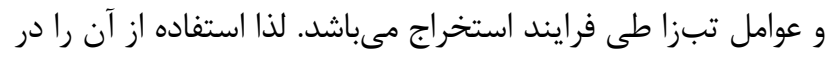

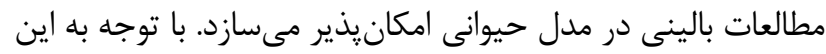

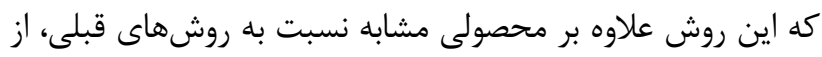

واكسن فرار مىكنند (vaccine escape mutant) باشد، مانند سويههايى كه يرتاكتين توليد نمى كنند، امروزه اين سويهها به

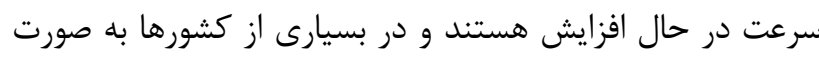

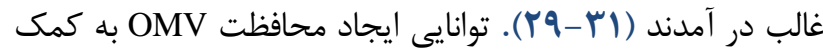

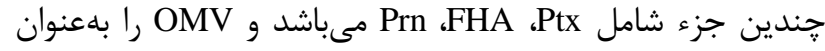
كانديد واكسنى مطرح مى كند كه فشار انتخابى روى سويه جهاى در

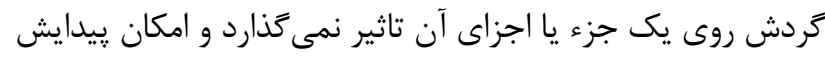

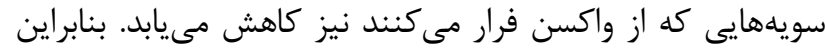

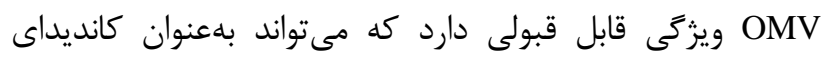
كاربردى واكسن يرتوسيس مطرح شود (1) Fernández استخراج شده از بردتلا برتوسيس را بهعنوان كانديد واكسن (OMV)

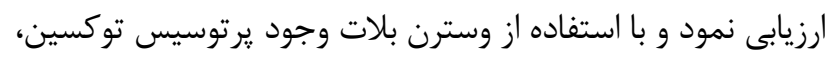

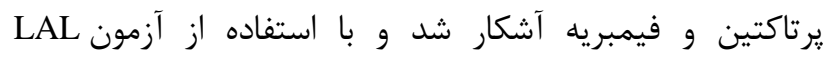
نشان داده شد كه سطح (Limulus Ambeocyte Lysate)

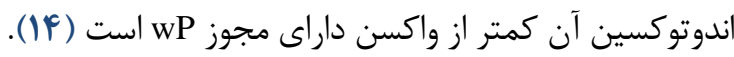
محتويات وزيكولهاى غشاى خارجى بردتلا برتوسيس سويه

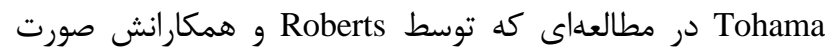
كرفت با استفاده از تكنيكهاى مختلف بررسى شد. نتايج وجود

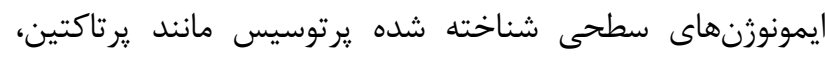
آدنيلات سيكلاز، برتوسيس توكسين و لييو اوليكوساكاريد را نشان مىدهد. با در نظر كرفتن القاء ايمنى ذاتى در مسيرهاى جريان هوان

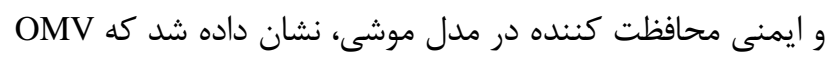

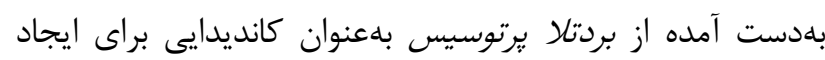
محافظت عليه يرتوسيس مطرح است (I) بردئ. در مطالعهاى كه بهوسيله Raeven در سال 9 ا.ب انجام شد امكان استفاده از OMVs بهعنوان كانديداى واكسن يرتوسيس داريس

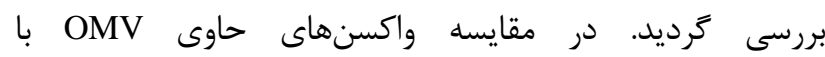

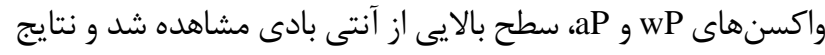

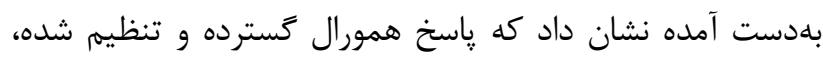

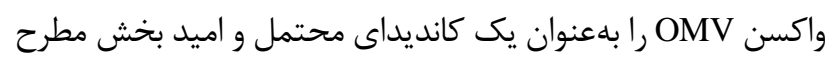

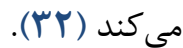

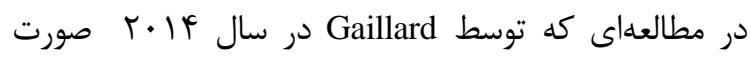

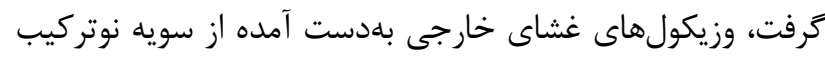

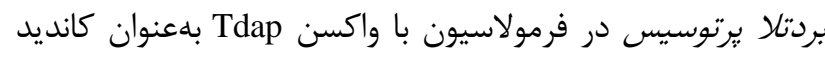
واكسن بررسى شدند و نتايج با واكسن تجارى رايج مقايسه شد.

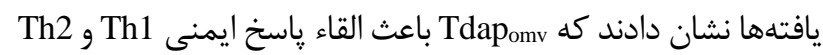




$$
\begin{aligned}
& \text { سياسگزارى } \\
& \text { بدينوسيله، از تمامى كسانى كه نويسندكان را در اين مقاله } \\
& \text { يارى كردهاند، قدردانى مىشود. } \\
& \text { تعارض در منافع }
\end{aligned}
$$

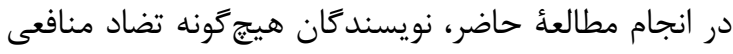$$
\text { نداشتهاند. }
$$

$$
\begin{aligned}
& \text { نظر امكانات و بعد اقتصادى نسبت به روش رايج مزاياى مثبتى دارد، } \\
& \text { مى تواند زمينهساز جداسازى وزيكولها در سطح وسيع و بدون نياز } \\
& \text { به دستخاه اولتراسانتريفيوز باشد. بهطورى كه OMVs سوينه }
\end{aligned}
$$

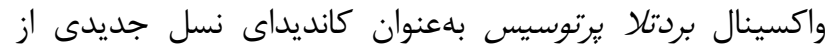

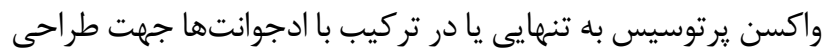

$$
\begin{aligned}
& \text { واكسنهاى آسلولار در آينده مطرح است. }
\end{aligned}
$$

\section{Referance}

1. Kerr J, Matthews R. Bordetella pertussis infection: pathogenesis, diagnosis, management, and the role of protective immunity. European Journal of Clinical Microbiology and Infectious Diseases. 2000;19(2):77-88. [DOI:10.1007/s100960050435] [PMID]

2. Edwards KM. Overview of pertussis: focus on epidemiology, sources of infection, and long term protection after infant vaccination. The Pediatric Infectious Disease Journal. 2005;24(6): 104-8. [DOI:10.1097/01.inf.0000166154.47013.47] [PMID]

3. Warfel JM, Edwards KM. Pertussis vaccines and the challenge of inducing durable immunity. Current Opinion in Immunology.

2015;35:48-54.

[DOI:10.1016/j.coi.2015.05.008] [PMID]

4. Willems RJ, Mooi FR. From whole cell to acellular pertussis vaccines. Reviews in Medical Microbiology. 1996;7(1):13-22. [DOI:10.1097/00013542-19960100000002]

5. Lugauer S, Heininger U, Cherry JD, Stehr K. Long-term clinical effectiveness of an acellular pertussis component vaccine and a whole cell pertussis component vaccine. European Journal of Pediatrics. 2002;161(3):142-6. [DOI:10.1007/s00431-001-0893-5] [PMID]

6. Denoël P, Godfroid F, Guiso N, Hallander H, Poolman J. Comparison of acellular pertussis vaccines-induced immunity against infection due to Bordetellapertussis variant isolates in a mouse model. Vaccine. 2005;23(4647):5333-41. [DOI:10.1016/j.vaccine.2005.06.021] [PMID]

7. Mooi FR, He Q, Guiso N. Phylogeny, evolution, and epidemiology of Bordetellae. Bordetella Molecular Microbiology. 2007:17-45.

8. Sealey KL, Belcher T, Preston A. Bordetella pertussis epidemiology and evolution in the light of pertussis resurgence. Infection, Genetics and Evolution. 2016;40:136-43. [DOI:10.1016/j.meegid.2016.02.032] [PMID]

9. Safarchi A, Octavia S, Nikbin VS, Lotfi MN, Zahraei SM, Tay CY, et al. Genomic epidemiology of Iranian Bordetella pertussis: 50 years after the implementation of whole cell vaccine. Emerging Microbes \& Infections. 2019;8(1):1416-27. [PMCID]

[PMID]

10. Mooi F, Van Der Maas N, De Melker H. Pertussis resurgence: waning immunity and pathogen adaptationtwo sides of the same coin. Epidemiology and Infection. 2014;142(04):685-94. [DOI:10.1017/S0950268813000071] [PMID]

11. Mooi FR, Van Loo I, Gent Mv, He Q, Bart MJ, Heuvelman KJ, et al. Bordetella pertussis strains with increased toxin production associated with pertussis resurgence. Emerging Infectious Diseases. 2009;15(8):1206-13. [DOI:10.3201/eid1508.081511] [PMID] [PMCID]

12. Roberts R, Moreno G, Bottero D, Gaillard ME, Fingermann M, Graieb A, et al. Outer membrane vesicles as acellular vaccine against pertussis. Vaccine. 2008;26(36):4639-46.

[DOI:10.1016/j.vaccine.2008.07.004] [PMID]

13. Ünal CM, Schaar V, Riesbeck K. Bacterial outer membrane vesicles in disease and preventive medicine. Seminars in Immunopathology. 2011;33(5):395-408. [DOI:10.1007/s00281-010-0231-y] [PMID]

14. Fernández S, Fajardo EM, Mandiarote A, Padrón MA, Acosta M, Cabrera RA, et al. A proteoliposome formulation derived from Bordetella pertussis induces protection in two murine challenge models. BMC Immunology. 2013;14(1):1-4. [DOI:10.1186/1471-217214-S1-S8] [PMID] [PMCID]

15. Kulp A, Kuehn MJ. Biological functions and biogenesis of secreted bacterial outer membrane vesicles. Annual Review of Microbiology. 2010;64:163-84. [DOI:10.1146/annurev.micro.091208.073413] [PMID] [PMCID]

16. Hozbor D, Rodriguez M, Fernandez J, Lagares A, Guiso N, Yantorno OJC. Release of outer membrane vesicles from Bordetella pertussis. Current Microbiology. 1999;38(5):273-8. [DOI:10.1007/PL00006801] [PMID]

17. Stainer D, Scholte M. A simple chemically defined medium for the production of phase I Bordetella pertussis. Microbiology. 1970;63(2):211-20. [DOI:10.1099/00221287-63-2-211] [PMID]
[DOI:10.1080/22221751.2019.1665479] 
18. Ormazábal M, Bartel E, Gaillard ME, Bottero D, Errea A, Zurita ME, et al. Characterization of the key antigenic components of pertussis vaccine based on outer membrane vesicles. Vaccine. 2014;32(46):6084-90. [DOI:10.1016/j.vaccine.2014.08.084] [PMID]

19. Ernst O, Zor T. Linearization of the Bradford protein assay. Journal of Visualized Experiment. 2010;38:1-6. [DOI:10.3791/1918] [PMID] [PMCID]

20. Laemmli UK. Cleavage of structural proteins during the assembly of the head of bacteriophage T4. Nature. 1970;227:680-5. [DOI:10.1038/227680a0] [PMID]

21. Pereira A, Pietro Pereira AS, Silva CL, de Melo Rocha G, Lebrun I, Sant'Anna OA, et al. Antibody response from whole-cell pertussis vaccine immunized Brazilian children against different strains of Bordetella pertussis. Am J Trop Med Hyg. 2010;82(4):678-82. [DOI:10.4269/ajtmh.2010.09-0486] [PMID] [PMCID]

22. Vipond C, Findlay L, Feavers I, Care R. Limitations of the rabbit pyrogen test for assessing meningococcal OMV based vaccines. ALTEX-Alternatives to Animal Experimentation. 2016;33(1):47-53. [DOI:10.14573/altex.1509291] [PMID]

23. Wilk MM, Borkner L, Misiak A, Curham L, Allen AC, Mills KH. Immunization with whole cell but not acellular pertussis vaccines primes CD4 TRM cells that sustain protective immunity against nasal colonization with Bordetella pertussis. Emerging microbes and infections. 2019;8(1):169-85.

[DOI:10.1080/22221751.2018.1564630] [PMID] [PMCID]

24. Locht C. Pertussis: acellular, whole-cell, new vaccines, what to choose? Expert review of vaccines. 2016;15(6):671-3.

[DOI:10.1586/14760584.2016.1161511] [PMID]

25. Guiso N. Bordetella pertussis and pertussis vaccines. Clinical Infectious Diseases. 2009;49(10):1565-9. [DOI:10.1086/644733] [PMID]

26. Hozbor DF. Outer membrane vesicles: an attractive candidate for pertussis vaccines. Expert Review of Vaccines. 2017;16(3):193-6. [DOI:10.1080/14760584.2017.1276832] [PMID]

27. Zurita ME, Wilk MW, Carriquiriborde F, Bartel E, Moreno GN, Misiak A, et al. A pertussis outer membrane vesicle-based vaccine induces lung-resident memory CD4 $\mathrm{T}$ cells and protection against Bordetella pertussis, including pertactin deficient strains. Frontiers in Cellular and Infection Microbiology. 2019;9:125-31. [DOI:10.3389/fcimb.2019.00125] [PMID] [PMCID]

28. He Q, Mertsola J. Factors contributing to pertussis resurgence. Future Microbiology. 2008;3(3):329-39. [DOI:10.2217/17460913.3.3.329] [PMID]

29. Tsang RS, Shuel M, Jamieson FB, Drews S, Hoang L, Horsman G, et al. Pertactin-negative Bordetella pertussis strains in Canada: characterization of a dozen isolates based on a survey of 224 samples collected in different parts of the country over the last 20 years. International Journal of Infectious Diseases. 2014;28:65-9. [DOI:10.1016/j.ijid.2014.08.002] [PMID]
30. Safarchi A, Octavia S, Luu LDW, Tay CY, Sintchenko V, Wood N, et al. Pertactin negative Bordetella pertussis demonstrates higher fitness under vaccine selection pressure in a mixed infection model. Vaccine. 2015;33(46):6277-81.

[DOI:10.1016/j.vaccine.2015.09.064] [PMID]

31. Martin SW, Pawloski L, Williams M, Weening K, DeBolt C, Qin X, et al. Pertactin-negative Bordetella pertussis strains: evidence for a possible selective advantage. Clinical Infectious Diseases. 2014;60(2):23-7. [DOI:10.1093/cid/ciu788] [PMID]

32. Raeven RH, Brummelman J, Pennings JL, Van Der Maas L, Tilstra W, Helm K, et al. Bordetella pertussis outer membrane vesicle vaccine confers equal efficacy in mice with milder inflammatory responses compared to a wholecell vaccine. Scientific Reports. 2016;6:1-8. [DOI:10.1038/srep38240] [PMID] [PMCID]

33. Gaillard ME, Bottero D, Errea A, Ormazábal M, Zurita ME, Moreno G, et al. Acellular pertussis vaccine based on outer membrane vesicles capable of conferring both longlasting immunity and protection against different strain genotypes. $\quad$ Vaccine. 2014;32(8):931-7. [DOI:10.1016/j.vaccine.2013.12.048] [PMID]

34. Bai X, Findlow J, Borrow R. Recombinant protein meningococcal serogroup $B$ vaccine combined with outer membrane vesicles. Expert Opinion on Biological Therapy. 2011;11(7):969-85. [DOI:10.1517/14712598.2011.585965] [PMID] 